\title{
Randomized clinical field trial on the effects of butaphosphan- cyanocobalamin and propylene glycol on ketosis resolution and milk production
}

\author{
J. L. Gordon, ${ }^{*}$ S. J. LeBlanc, ${ }^{*}$ D. F. Kelton, ${ }^{*}$ T. H. Herdt, $\dagger$ L. Neuder, $†$ and T. F. Duffield ${ }^{* 1}$ \\ *Department of Population Medicine, University of Guelph, Guelph, ON, N1G 2W1, Canada \\ †Department of Large Animal Clinical Sciences, Michigan State University, East Lansing 48824
}

\begin{abstract}
The purpose of this study was to determine the effects of a butaphosphan-cyanocobalamin combination product $(\mathrm{B}+\mathrm{C})$ and 2 durations of propylene glycol treatment (PG; 3 versus $5 \mathrm{~d}$ ) on ketosis resolution and early lactation milk yield. Cows from 9 freestall herds (8 in Ontario and 1 in Michigan) were tested at weekly intervals between 3 and $16 \mathrm{~d}$ in milk. Ketosis was defined as blood $\beta$-hydroxybutyrate (BHB) $\geq 1.2 \mathrm{mmol} / \mathrm{L}$. Ketotic cows were randomly assigned to treatment with $25 \mathrm{~mL}$ of $\mathrm{B}+\mathrm{C}$ or $25 \mathrm{~mL}$ of saline placebo for $3 \mathrm{~d}$ and 3 or $5 \mathrm{~d}$ of $300 \mathrm{~g}$ of $\mathrm{PG}$ orally in a $2 \times 2$ factorial arrangement. Outcomes evaluated for all farms included ketosis cure (blood BHB $<1.2 \mathrm{mmol} / \mathrm{L}$ at 1 wk after enrollment), maintenance of ketosis cure (blood BHB $<1.2 \mathrm{mmol} / \mathrm{L} 1$ and 2 wk after enrollment), and blood BHB concentrations at 1 and 2 wk after enrollment. Daily milk weights were collected in 3 herds. Poisson regression was used to evaluate cure and maintenance of cure, whereas repeated-measures ANOVA was used to evaluate blood BHB concentrations in the 2 wk after enrollment and average daily milk production in the 30 d after treatment. A total of 594 animals were enrolled in the study with 124 treated with $\mathrm{B}+\mathrm{C}$ and $5 \mathrm{~d}$ of $\mathrm{PG}$, 176 treated with $\mathrm{B}+\mathrm{C}$ and $3 \mathrm{~d}$ of $\mathrm{PG}, 128$ treated with saline and $5 \mathrm{~d}$ of $\mathrm{PG}$, and 166 treated with saline and $3 \mathrm{~d}$ of PG. Animals with blood BHB $>2.4 \mathrm{mmol} / \mathrm{L}$ at the time of enrollment were 1.7 times more likely [95\% confidence interval (CI): 1.4 to 2.2] to cure and had a decrease of $0.25 \pm 0.11 \mathrm{mmol} / \mathrm{L}$ blood $\mathrm{BHB}$ at $1 \mathrm{wk}$ after enrollment if treated with $5 \mathrm{~d}$ of $\mathrm{PG}$ compared with $3 \mathrm{~d}$, though this response was not seen in animals with $\mathrm{BHB}$ of 1.2 to $2.4 \mathrm{mmol} / \mathrm{L}$ at enrollment. Cows with blood glucose concentrations $<2.2 \mathrm{mmol} / \mathrm{L}$ at enrollment produced $3.1 \mathrm{~kg} / \mathrm{d}$ (95\% CI: 1.3 to 5.0$)$ more milk if treated with $\mathrm{B}+\mathrm{C}$ and $3.4 \mathrm{~kg} / \mathrm{d}(95 \% \mathrm{CI}: 1.7$ to
\end{abstract}

Received August 26, 2016.

Accepted January 13, 2017.

${ }^{1}$ Corresponding author: tduffiel@uoguelph.ca
5.1) more milk if treated with $5 \mathrm{~d}$ of $\mathrm{PG}$ compared with their respective controls. This response was not seen in animals with blood glucose $\geq 2.2 \mathrm{mmol} / \mathrm{L}$ at enrollment and there was no interaction between treatments. These results indicate that extended PG treatment is beneficial in decreasing blood BHB concentrations in more severely affected animals. Additionally, both $\mathrm{B}+\mathrm{C}$ treatment and extended $\mathrm{PG}$ treatment improved milk yield in animals with low blood glucose at the time of ketosis diagnosis.

Key words: ketosis, cyanocobalamin, propylene glycol, glucose

\section{INTRODUCTION}

Metabolic disease is common in early lactation dairy cattle due to a period of negative energy balance that occurs at the beginning of lactation for nearly every animal (Bauman and Currie, 1980; Baird, 1982; Herdt, 2000). Lactation is given a high priority in metabolic demands, to the point that body stores are heavily utilized to support lactation (Bauman and Currie, 1980). Adaptations occur in many animals that allow changes in physiology and metabolism to support lactation without subsequent disease through a process of homeorhesis (Bauman and Currie, 1980). However, in some animals, these adaptations are inadequate and metabolic disease results, often in the form of hyperketonemia (Bauman and Currie, 1980; Herdt, 2000).

Production of ketone bodies is part of the homeorhetic changes that allow lactation to proceed and support higher levels of production (Herdt, 2000). However, pathologic levels of ketone bodies are associated with increased risk of displaced abomasum, poorer reproductive performance, and decreased milk production (Duffield et al., 2009; Ospina et al., 2010a,b; McArt et al., 2012b). All of these outcomes can lead to decreased animal welfare and economic losses for the producer.

Glucose is required for milk production and is an important part of the endocrine mechanisms that control homeorhesis in early lactation (Herdt, 2000). Blood 
ketones and glucose generally have an inverse relationship, as low blood glucose concentrations stimulate fat breakdown and ketone production (Herdt, 2000). However, animals have varying abilities to compensate and homeorhetic mechanisms do not function to the same extent in all animals. Thus, some animals with high blood ketones may have normal or high blood glucose (Herdt, 2000). This suggests a difference in the mechanism of ketosis development and may play an important role in the effectiveness of ketosis treatment regimens (Herdt, 2000; Gordon et al., 2012).

Propylene glycol (PG) was first described for ketosis treatment in 1954 (Johnson, 1954; Maplesden, 1954). When PG enters the rumen, it is either absorbed directly or converted to propionate; PG that is absorbed directly stimulates gluconeogenesis by entering the tricarboxylic acid (TCA) cycle (Nielsen and Ingvartsen, 2004). Propionate produced from metabolism of PG can be used as a precursor for gluconeogenesis and helps stimulate insulin release to decrease fat catabolism (Studer et al., 1993). Although PG has often been studied (Nielsen and Ingvartsen, 2004), many of these studies were small or poorly designed. Recently, a largescale clinical field trial illustrated the benefits of $\mathrm{PG}$ use for treatment of subclinical ketosis (McArt et al., 2011, 2012a). Cows in that study were tested for ketosis 3 times a week and treated with PG until ketosis was resolved, from 2 to $16 \mathrm{~d}$. Although the study showed several benefits of treatment with PG, there were 2 challenges with the study design. Giving an oral drench of PG is labor intensive and the results do not identify a minimum effective duration of treatment. Additionally, animals with $\mathrm{BHB} \geq 3.0 \mathrm{mmol} / \mathrm{L}$ were removed from the trial, so it is unclear whether more severely affected animals benefit from PG treatment.

Recently, a combination butaphosphan and cyanocobalamin product $(\mathbf{B}+\mathbf{C}$, Catosal, Bayer, Shawnee, KS) has been investigated for ketosis treatment (Lohr et al., 2006; Gordon et al., 2012). Cyanocobalamin is a form of vitamin $\mathrm{B}_{12}$, which has been hypothesized to increase gluconeogenesis by increasing the activity of methylmalonyl-CoA mutase, a vitamin $\mathrm{B}_{12}$-dependent enzyme and important component of the TCA cycle (Kennedy et al., 1990). Butaphosphan, an organic phosphorus source, might also stimulate gluconeogenesis by phosphorylating intermediate compounds in the process (Rollin et al., 2010). However, it is unclear whether this form of phosphorus is biologically available to the animal. The use of this combination product has been shown to increase rumination in cows after surgical correction of a left displaced abomasum (Lohr et al., 2006) and to increase ketosis cure and milk production in multiparous cows (Gordon et al., 2012). Data from these studies were collected subjectively (Lohr et al.,
2006) or from a single herd (Gordon et al., 2012), so it is unclear how efficacious $\mathrm{B}+\mathrm{C}$ would be in various commercial herds.

The objective of this study was to examine the effects of $\mathrm{B}+\mathrm{C}$ and varying durations of $\mathrm{PG}$ treatment for resolution of ketosis and the effects on early lactation milk production. A secondary objective was to examine the association between blood glucose concentration at enrollment and treatment outcomes.

\section{MATERIALS AND METHODS}

\section{Study Population}

Data were collected from 8 dairy herds in Ontario (farms A through $\mathrm{H}$ ) and 1 in Michigan (farm Z) from May 14 to August 27, 2012. Herds were purposively selected due to their proximity to study sites and willingness to participate. To be eligible for inclusion, herds were required to be enrolled in monthly milk testing through their local DHI organization or to collect daily milk weights on farm. Enrolled herds were housed in freestall facilities ranging from 100 to 3,200 lactating cows. All herds delivered a TMR to all lactating cows.

\section{Data Collection and Study Design}

Herds were visited weekly during the study period. Individual herds were visited on the same day of the week and at the same time of day. At each visit, cows 3 to 16 DIM were tested for ketosis using the Precision Xtra meter (Abbott Laboratories, Abbott Park, IL). Cows were excluded from enrollment if they had been previously diagnosed with ketosis or a DA or had been enrolled in the study the previous week. Ketosis was defined a priori as blood BHB $\geq 1.2 \mathrm{mmol} / \mathrm{L}$. The Precision Xtra meter is a handheld device that measures BHB in whole blood. This meter has previously been validated for use in cattle and has $88 \%$ sensitivity and $96 \%$ specificity at this cut-point (Iwersen et al., 2009). This testing scheme provided 2 opportunities for enrollment for each animal, once at 3 to 9 DIM and again at 10 to 16 DIM.

Blood was drawn from the coccygeal vessels using a 20 -gauge $\times 2.54$-cm needle and 3 - $\mathrm{mL}$ syringe. Ketone testing was performed immediately according to manufacturer's instructions. In animals that were classified as ketotic (blood BHB $\geq 1.2 \mathrm{mmol} / \mathrm{L}$ ), blood glucose concentration was measured using a second Precision Xtra meter. Blood was tested for glucose immediately after the ketone results were displayed (10 s from application of blood to the strip) and were displayed after $5 \mathrm{~s}$. The use of Precision Xtra for glucose determination has also been validated in cattle (sensitivity $76.2 \%$, 
specificity $92.7 \%$ at $2.2 \mathrm{mmol} / \mathrm{L}$ cut-point, Wittrock et al., 2013).

Animals classified as ketotic were randomly assigned to 1 of 4 treatment groups in a $2 \times 2$ factorial arrangement: (1) $25 \mathrm{~mL}$ of $\mathrm{B}+\mathrm{C}$ subcutaneously once a day for $3 \mathrm{~d}$ and $300 \mathrm{~g}$ of $\mathrm{PG}$ via oral drench once a day for 5 $\mathrm{d}$; (2) $3 \mathrm{~d}$ of B+C and $3 \mathrm{~d}$ of PG, (3) $25 \mathrm{~mL}$ of placebo (sterile $0.9 \%$ saline) subcutaneously once a day for $3 \mathrm{~d}$ and PG for $5 \mathrm{~d}$; or (4) $3 \mathrm{~d}$ of placebo and $3 \mathrm{~d}$ of PG. In 3 of the study herds, $5 \mathrm{~d}$ of administration of PG was not possible due to labor constraints and animals were randomly assigned to treatment with $3 \mathrm{~d}$ of $\mathrm{B}+\mathrm{C}$ and $3 \mathrm{~d}$ of PG or $3 \mathrm{~d}$ of placebo and $3 \mathrm{~d}$ of PG. The concentration of $\mathrm{PG}$ in the drench varied by study site, so animals were treated with $450 \mathrm{~mL}$ of liquid $(67 \% \mathrm{PG}$, Glycol-P, Vetoquinol, Lavaltrie, QC, Canada) in herds in Ontario or $300 \mathrm{~mL}$ of liquid $(100 \% \mathrm{PG})$ in the herd in Michigan. The label dose for $\mathrm{B}+\mathrm{C}$ is $2 \mathrm{~mL} / 45 \mathrm{~kg}$ of BW. A fixed volume dose of $25 \mathrm{~mL}$ was selected for convenience, to maintain consistency across study sites and to facilitate blinding. Subcutaneous injections were split so a maximum of $10 \mathrm{~mL}$ was administered per site. Randomization was performed using a random number generator so that sequential blocks of 4 cows included 1 cow of each treatment group. In the Michigan herd, treatments were randomized separately for primiparous and multiparous animals. In Ontario herds, all animals within a herd were included on the same randomization list. Individuals performing the testing and assigning and administering treatments, farm personnel, and veterinarians were blinded to $\mathrm{B}+\mathrm{C}$ treatment. Farm personnel and veterinarians were blinded to the duration of PG treatment as all treatments were administered by study personnel.

Enrolled cows were tested for blood BHB and glucose concentrations at weekly intervals for 2 wk after treatment. Further data collected included lactation number, DIM at enrollment, and daily milk weights for the first $30 \mathrm{~d}$ in lactation (farms C, H, and Z). Milk weights were exported from DairyComp 305 (Valley Agricultural Software, Tulare, CA) or AfiFarm (Afimilk, Kibbutz Afikim, Israel) throughout the study period. Milk weights recorded as "0" were re-entered as missing data points. Animals were excluded from analysis if they did not receive treatments, were not tested at 1 and $2 \mathrm{wk}$ after treatment, or died or were sold before 2 wk after treatment. Animals were excluded from milk analysis if they had fewer than 10 daily milk weights during the study period.

The people responsible for health of the animals on the farm were allowed to treat enrolled animals for other significant diseases as needed after the first $5 \mathrm{~d}$ of study treatment. They were asked to record any ad- ditional treatments given and this was included in the analyses as covariates. Study personnel verbally confirmed whether or not additional treatments had been administered to enrolled animals on a weekly basis.

Based on sample size calculations, this study was designed to screen 1,600 cows. With an expected ketosis incidence of $20 \%$, this would yield 320 cows with ketosis and 80 cows per treatment group. Given $95 \%$ confidence, $80 \%$ power, and $0.45 \mathrm{mmol} / \mathrm{L}$ standard deviation of $\mathrm{BHB}$, this sample size would allow for detection of a 0.2 $\mathrm{mmol} / \mathrm{L}$ difference in blood BHB between treatment groups. The proposal was approved by the University of Guelph Animal Care Committee (11R036) and the Michigan State University Institutional Animal Care and Use Committee (\#04/11-078-00).

\section{Statistical Analysis}

Statistical analyses were completed in SAS (version 9.3; SAS Institute Inc., Cary, NC). The outcomes of interest were cure at $1 \mathrm{wk}$ post-treatment, maintenance of cure at 2 wk post-treatment, blood BHB concentrations at 1 and 2 wk post-treatment, and milk production for $30 \mathrm{~d}$ after treatment. Cure was defined as blood BHB $<1.2 \mathrm{mmol} / \mathrm{L}$ at $1 \mathrm{wk}$ post-treatment. Maintenance of cure was defined as blood BHB $<1.2 \mathrm{mmol} / \mathrm{L}$ at 1 and 2 wk post-treatment. Continuous variables (DIM at enrollment, BHB and glucose at all 3 time points) were examined for normality and linearity. Days in milk was categorized in 2 ways, enrollment at wk 1 (3 to 9 DIM) versus wk 2 (10 to 16 DIM) and early (3 to 5 DIM) versus late (6 to 16 DIM). Glucose was categorized into $\geq 2.2 \mathrm{mmol} / \mathrm{L}$ and $<2.2 \mathrm{mmol} / \mathrm{L}$ (low) based on sensitivity analysis (sensitivity $74.2 \%$, specificity $74.3 \%$; Gordon, 2013) and was offered to models in 1 of 2 forms, as either a linear or a categorical predictor. A natural log-transformation was used with BHB values 1 and 2 wk post-treatment. An effective transformation could not be identified to normalize enrollment BHB concentrations, so it was categorized into moderate (1.2 to $2.4 \mathrm{mmol} / \mathrm{L})$ and high $(>2.4 \mathrm{mmol} / \mathrm{L})$ based on sensitivity analysis (sensitivity $44.6 \%$, specificity $76.2 \%$; Gordon, 2013). Parity was divided into 1, 2, and 3+ lactations. Descriptive statistics were generated using PROC FREQ and PROC MEANS in SAS. Each variable was examined for association with the selected outcomes using contingency tables and the Chi-squared statistic for categorical variables and univariable linear regression for continuous variables using PROC GLM. Any variable with $P \leq 0.2$ was offered to multivariable models.

For the outcomes cure and maintenance of cure, Poisson regression was used (PROC GENMOD in 
SAS) with a log link, Poisson distribution, and an exchangeable correlation structure. Clustering by herd and overdispersion were accounted for in the model by including a random herd effect in the model. A mixed model (PROC MIXED in SAS) was used to examine the effects of treatment on BHB concentrations 1 and 2 wk post-treatment and milk production in the first $30 \mathrm{~d}$ after treatment with cow as a repeated measure and a first-order autoregressive correlation structure. Numerous correlation structures were examined and the model with the lowest Akaike information criterion (AIC) was selected.

All variables with a univariate association with the outcome $(P \leq 0.2)$ were offered to the respective multivariable models. Models were built manually via backward stepwise elimination, with the variables with the highest $P$-values removed first until only variables associated with the outcome $(P \leq 0.05)$ remained. At removal of each variable, the model was examined for evidence of confounding (changes in coefficients by $>20 \%$ ). Treatments $(\mathrm{B}+\mathrm{C}$ and $\mathrm{PG}$ duration) were retained in the models regardless of $P$-value. If the 2 forms of a variable (linear and categorical or 2 categorization schemes) were both significantly associated with the outcome, they were tested in separate backward stepwise multivariable models and the model with the lowest AIC or quasi-likelihood under the independence model criterion (QIC) was selected. Interactions were formed between treatments and retained if significant. Next, interactions were formed between other variables in the final model and retained if biologically relevant and significant $(P \leq 0.05)$. If treatment was part of a significant interaction with another predictor, the outcome was stratified by the predictor and stratumspecific results presented.

Variables offered to the model for ketosis cure included enrollment BHB group (1.2 to 2.4 vs. $>2.4 \mathrm{mmol} / \mathrm{L}$; $P=0.001)$, parity $(P<0.001)$, glucose group $(<2.2$ vs. $\geq 2.2 \mathrm{mmol} / \mathrm{L} ; P=0.002)$, week of enrollment $(P$ $=0.2)$, early ( 3 to $5 \mathrm{DIM})$ versus late (6 to $16 \mathrm{DIM})$ enrollment $(P=0.1), \mathrm{B}+\mathrm{C}(P=0.3)$, and length of $\mathrm{PG}$ treatment ( 3 vs. $5 \mathrm{~d} ; P=0.5$ ). Variables offered to the model for maintenance of ketosis cure $(\mathrm{n}=252$ cows $)$ included enrollment BHB group $(P<0.001)$, parity $(P$ $<0.001)$, glucose group $(P<0.001)$, week of enrollment $(P=0.1)$, early versus late enrollment $(P=0.1)$, $\mathrm{B}+\mathrm{C}(P=0.9)$, and length of $\mathrm{PG}$ treatment $(P=0.8)$.

Variables offered to the models for effect of treatment on blood BHB concentrations at 1 and $2 \mathrm{wk}$ post-enrollment included enrollment BHB group $(P<$ $0.001)$, parity $(P<0.001)$, glucose group $(P<0.001)$, $\mathrm{B}+\mathrm{C}(P=0.2)$, and $\mathrm{PG}$ treatment length $(P=0.6)$. In addition, week of enrollment $(P=0.06)$ or early versus late enrollment $(P=0.1)$ were offered to the model for the effects on blood BHB concentrations at $1 \mathrm{wk}$ post-enrollment.

Variables offered to the model for milk production in the $30 \mathrm{~d}$ after enrollment included parity $(P<0.001)$, glucose group $(P<0.001)$, month of calving $(P<$ $0.001)$, week of enrollment $(P<0.001)$, early versus late enrollment $(P=0.1), \mathrm{B}+\mathrm{C}(P=0.2)$, and $\mathrm{PG}$ duration ( 3 vs. $5 \mathrm{~d}, P=0.03$ ).

\section{RESULTS}

\section{Descriptive Statistics}

Of the 1,742 cows tested, 763 were diagnosed with ketosis (blood BHB $\geq 1.2 \mathrm{mmol} / \mathrm{L}, 44 \%$ ). Herd incidence ranged from 31 to $69 \%$. In total, 601 cows were diagnosed as ketotic (78\%) between 3 and 9 DIM and $162(22 \%)$ between 10 and 16 DIM. Because of labor constraints, a maximum number of cows could be enrolled per herd per week, so 120 of these animals were not enrolled. A further 49 animals were lost to follow up because they did not receive study treatments $(\mathrm{n}=$ $12)$, were missed on follow-up testing $(\mathrm{n}=15)$, were enrolled in the study twice $(\mathrm{n}=2)$, died $(\mathrm{n}=12)$, or were sold $(\mathrm{n}=8)$. This left 594 animals for analysis.

Descriptive statistics are provided in Tables 1 and 2 . There was no difference in lactation number, DIM at enrollment, or BHB concentrations at enrollment between study groups $(P>0.5)$. One hundred sixty-seven cows $(28 \%)$ had enrollment BHB $>2.4 \mathrm{mmol} / \mathrm{L}$ and 220 (37\%) had enrollment glucose $<2.2 \mathrm{mmol} / \mathrm{L}$. These 2 measures did not differ between treatment groups $(P$ $>0.5)$.

\section{Effect of Treatment on Ketosis Resolution}

Overall, $42 \%$ of cows had resolved ketosis 1 wk after diagnosis. Enrollment in the first week (3 to 9 DIM), blood glucose concentrations $<2.2 \mathrm{mmol} / \mathrm{L}$ at enrollment, and parity $>1$ were associated with significantly decreased cure risk (Table 3 ). The $\mathrm{B}+\mathrm{C}$ treatment had no effect on cure risk $(P=0.5)$ and there was no interaction between treatments $(P=0.2)$. We detected a significant interaction between blood BHB at enrollment and length of $\mathrm{PG}$ treatment $(P<0.001)$. The $P G$ treatment did not affect cure risk in animals with blood BHB 1.2 to $2.4 \mathrm{mmol} / \mathrm{L}$ at enrollment $(\mathrm{n}=427$; $P=0.7)$, but animals with blood $\mathrm{BHB}>2.4 \mathrm{mmol} / \mathrm{L}$ at enrollment $(\mathrm{n}=167)$ were 1.7 times more likely to cure if treated with 5 d of PG versus 3 d (95\% CI: 1.4 to $2.2, P<0.001 ; 30$ vs. $18 \%$, respectively). None of the variables measured had a significant association with maintenance of ketosis cure $(P=0.2$ to 0.9$)$. 
Table 1. Descriptive statistics for 594 animals from 9 herds enrolled in a ketosis treatment trial with $10 \%$ butaphosphan-cyanocobalamin $(\mathrm{B}+\mathrm{C})$ and varying lengths of propylene glycol $(\mathrm{PG})$ treatment $^{1}$

\begin{tabular}{lccccc}
\hline Variable & Mean & Median & SD & Minimum & Maximum \\
\hline Lactation & 2.7 & 3.0 & 1.5 & 1 & 12 \\
DIM at enrollment (d) & 7 & 7 & 3.3 & 3 & 16 \\
BHB (mmol/L) & 2.2 & 1.8 & 1.1 & 1.2 & 7.5 \\
At enrollment & 1.8 & 1.3 & 1.4 & 0.2 & 8.7 \\
1 wk post-treatment & 1.8 & 1.2 & 1.5 & 0.2 & 8.7 \\
2 wk post-treatment & 2.3 & 2.3 & 0.6 & 0.1 & 5.9 \\
Glucose (mmol/L) & 2.6 & 2.6 & 0.7 & 0.1 & 5.1 \\
At enrollment & 2.7 & 2.7 & 0.7 & 0.2 & 6.2 \\
1 wk post-treatment & & & & \\
2 wk post-treatment & &
\end{tabular}

${ }^{1}$ Cows were randomly assigned to treatment with $\mathrm{B}+\mathrm{C}$ and $5 \mathrm{~d}$ of $\mathrm{PG}(\mathrm{n}=124), \mathrm{B}+\mathrm{C}$ and $3 \mathrm{~d}$ of $\mathrm{PG}(\mathrm{n}=$ 176), placebo and $5 \mathrm{~d}$ of $\mathrm{PG}(\mathrm{n}=128)$, or placebo and $3 \mathrm{~d}$ of $\mathrm{PG}(\mathrm{n}=166)$ at ketosis diagnosis between 3 and 16 DIM. Ketosis was defined as blood BHB $\geq 1.2 \mathrm{mmol} / \mathrm{L}$

Table 2. Descriptive statistics for 594 animals from 9 herds enrolled in a ketosis treatment trial utilizing 10\% butaphosphan-cyanocobalamin $(\mathrm{B}+\mathrm{C})$ and varying lengths of propylene glycol $(\mathrm{PG})$ treatment

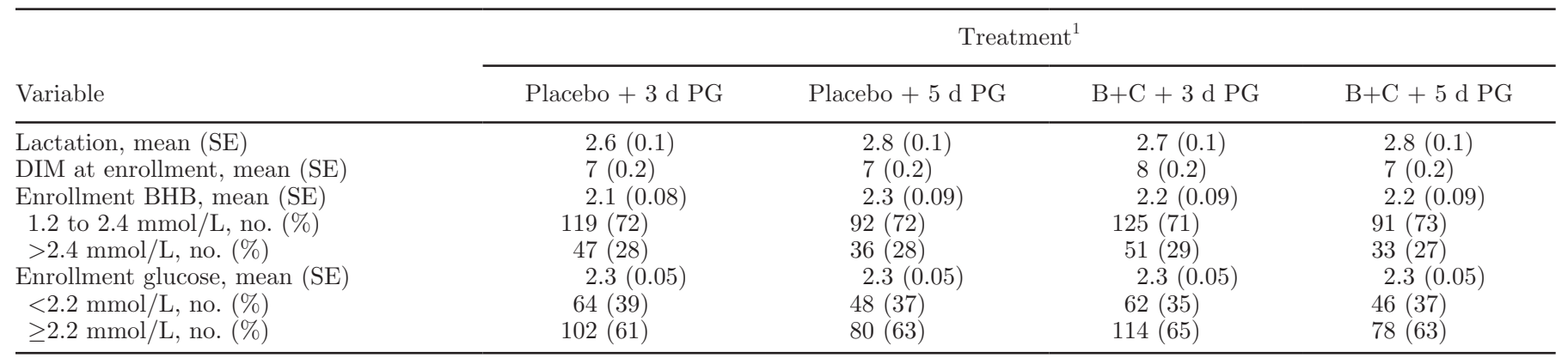

${ }^{1}$ Cows were randomly assigned to treatment with $\mathrm{B}+\mathrm{C}$ and $5 \mathrm{~d}$ of $\mathrm{PG}(\mathrm{n}=124), \mathrm{B}+\mathrm{C}$ and $3 \mathrm{~d}$ of $\mathrm{PG}(\mathrm{n}=176)$, placebo and $5 \mathrm{~d}$ of $\mathrm{PG}(\mathrm{n}=$ $128)$, or placebo and $3 \mathrm{~d}$ of PG $(\mathrm{n}=166)$ at ketosis diagnosis between 3 and 16 DIM. Ketosis was defined as blood BHB $\geq 1.2 \mathrm{mmol} / \mathrm{L}$.

Table 3. Final Poisson regression model of the probability of ketosis cure in 594 Holsteins from 9 herds $^{1}$

\begin{tabular}{|c|c|c|c|c|c|}
\hline Variable & $\beta$ coefficient & $\mathrm{SE}$ & $P$-value & Relative risk & $95 \% \mathrm{CI}$ \\
\hline Intercept & -0.29 & 0.07 & $<0.001$ & - & - \\
\hline \multicolumn{6}{|l|}{ Enrollment BHB } \\
\hline 1.2 to $2.4 \mathrm{mmol} / \mathrm{L}$ & Referent & - & - & - & - \\
\hline$>2.4 \mathrm{mmol} / \mathrm{L}$ & -0.52 & 0.14 & $<0.001$ & 0.6 & 0.4 to 0.8 \\
\hline \multicolumn{6}{|l|}{ Week of enrollment ${ }^{2}$} \\
\hline 1 & -0.17 & 0.06 & 0.004 & 0.8 & 0.7 to 0.9 \\
\hline 2 & Referent & - & - & - & - \\
\hline \multicolumn{6}{|l|}{ Glucose group } \\
\hline$<2.2 \mathrm{mmol} / \mathrm{L}$ & -0.42 & 0.19 & 0.03 & 0.7 & 0.5 to 0.9 \\
\hline$\geq 2.2 \mathrm{mmol} / \mathrm{L}$ & Referent & - & - & - & - \\
\hline \multicolumn{6}{|l|}{ Parity } \\
\hline 1 & Referent & - & - & - & - \\
\hline 2 & -0.28 & 0.14 & $<0.001$ & 0.8 & 0.6 to 0.9 \\
\hline $3+$ & -0.39 & 0.10 & $<0.001$ & 0.7 & 0.6 to 0.8 \\
\hline \multicolumn{6}{|l|}{$P G$} \\
\hline $3 \mathrm{~d}$ & Referent & - & - & - & - \\
\hline $5 \mathrm{~d}$ & 0.28 & 0.07 & $<0.001$ & 1.3 & 1.2 to 1.5 \\
\hline \multicolumn{6}{|l|}{$\mathrm{B}+\mathrm{C}$} \\
\hline No & Referent & - & - & - & - \\
\hline Yes & -0.03 & 0.05 & 0.5 & 1.0 & 0.9 to 1.1 \\
\hline $\mathrm{PG} \times$ Enrollment $\mathrm{BHB}$ & & & $<0.001$ & & \\
\hline
\end{tabular}

${ }^{1}$ Cows were randomly assigned to treatment with $10 \%$ butaphosphan-cyanocobalamin $(\mathrm{B}+\mathrm{C})$ and $5 \mathrm{~d}$ of $\mathrm{PG}$ (propylene glycol; $\mathrm{n}=124), \mathrm{B}+\mathrm{C}$ and $3 \mathrm{~d}$ of $\mathrm{PG}(\mathrm{n}=176)$, placebo and $5 \mathrm{~d}$ of $\mathrm{PG}(\mathrm{n}=128)$, or placebo and 3 $\mathrm{d}$ of PG ( $\mathrm{n}=166)$ at ketosis diagnosis between 3 and 16 DIM. Ketosis was defined as blood BHB $\geq 1.2 \mathrm{mmol} / \mathrm{L}$ and cure was defined as blood $\mathrm{BHB}<1.2 \mathrm{mmol} / \mathrm{L} 1 \mathrm{wk}$ after treatment.

${ }^{2}$ Week of enrollment was defined as 3 to 9 DIM (wk 1) or 10 to 16 DIM (wk 2). 
Table 4. Final model for blood BHB concentrations 1 wk after treatment, accounting for repeated measures, in 594 Holsteins from 9 herds $^{1}$

\begin{tabular}{lccc}
\hline Variable & $\beta$ coefficient & SE & $P$-value \\
\hline Intercept & -0.18 & 0.08 & 0.08 \\
Enrollment BHB & Referent & - & - \\
1.2 to $2.4 \mathrm{mmol} / \mathrm{L}$ & 0.34 & 0.07 & $<0.001$ \\
$>2.4 \mathrm{mmol} / \mathrm{L}$ & & & \\
Glucose group & Referent & - & - \\
$<2.2 \mathrm{mmol} / \mathrm{L}$ & 0.29 & 0.06 & $<0.001$ \\
$\geq 2.2 \mathrm{mmol} / \mathrm{L}$ & & & \\
Parity & Referent & - & - \\
1 & 0.23 & 0.09 & 0.003 \\
2 & 0.30 & 0.08 & 0.003 \\
$3+$ & & & \\
$\mathrm{PG}$ & Referent & - & - \\
$3 \mathrm{~d}$ & -0.11 & 0.06 & 0.08 \\
$5 \mathrm{~d}$ & & & \\
$\mathrm{~B}+\mathrm{C}$ & Referent & - & - \\
No & -0.09 & 0.05 & 0.1 \\
Yes & - & - & 0.03 \\
PG $\times$ Enrollment BHB & & - & \\
\hline
\end{tabular}

${ }^{1}$ Cows were randomly assigned to treatment with $10 \%$ butaphosphancyanocobalamin $(\mathrm{B}+\mathrm{C})$ and $5 \mathrm{~d}$ of $\mathrm{PG}$ (propylene glycol; $\mathrm{n}=124$ ), $\mathrm{B}+\mathrm{C}$ and $3 \mathrm{~d}$ of $\mathrm{PG}(\mathrm{n}=176)$, placebo and $5 \mathrm{~d}$ of $\mathrm{PG}(\mathrm{n}=128)$, or placebo and 3 d of $\mathrm{PG}(\mathrm{n}=166)$ at ketosis diagnosis between 3 and 16 DIM. Ketosis was defined as blood BHB $\geq 1.2 \mathrm{mmol} / \mathrm{L}$.

\section{Effect of Treatment on Blood BHB Concentrations}

The final models for blood BHB concentration 1 and 2 wk after enrollment are presented in Tables 4 and 5 , respectively. Low blood glucose at diagnosis and parity $>1$ were associated with significantly higher blood BHB concentrations at 1 and 2 wk after enrollment. Treatment $\mathrm{B}+\mathrm{C}$ had no significant effect on blood BHB concentrations at either time point and we found no interaction between treatments $(P=0.4$ and 0.9$)$.

In the model for blood BHB concentrations $1 \mathrm{wk}$ after enrollment, there was a significant interaction between BHB concentrations at enrollment and length of PG treatment $(P=0.03)$. Extended $P G$ treatment had no significant effect on blood BHB concentrations at $1 \mathrm{wk}$ after enrollment $(\mathrm{BHB}=1.5 \pm 1.2 \mathrm{mmol} / \mathrm{L})$ for animals with moderate blood BHB concentrations at enrollment $(P=0.7)$. However, animals with blood BHB $>2.4 \mathrm{mmol} / \mathrm{L}$ at enrollment had a significantly greater reduction $(-0.25 \pm 0.11 \mathrm{mmol} / \mathrm{L})$ in blood BHB concentrations $1 \mathrm{wk}$ after enrollment when treated with $5 \mathrm{~d}$ of PG $(P=0.02)$ compared with only $3 \mathrm{~d}$ of $\mathrm{PG}$ treatment.

We detected no effect of PG duration on BHB concentrations at the second follow-up test. Although blood BHB concentrations $>2.4 \mathrm{mmol} / \mathrm{L}$ at enrollment were associated with significantly higher BHB concentrations at the second follow-up test $(P=0.02)$, there were no interactions between enrollment BHB concentrations and treatment at this time point $(P=0.6)$.

\section{Effect of Treatment on Daily Milk Production for 30 Days After Enrollment}

The final model for milk production is presented in Table 6. Milk production per day decreased as animals calved later in the summer. Animals that were diagnosed with ketosis at the first test ( 3 to 9 DIM) produced $2.4 \mathrm{~kg} / \mathrm{d}$ less milk than animals that were diagnosed at the second test (10 to 16 DIM). There was no interaction between treatments $(P=0.5)$. However, there were significant interactions between blood glucose at enrollment and both $\mathrm{B}+\mathrm{C}$ treatment and $\mathrm{PG}$ treatment length. Treatment effects stratified by blood glucose at enrollment are provided in Table 7. Neither treatment had a significant effect on milk production in animals that had blood glucose $\geq 2.2 \mathrm{mmol} / \mathrm{L}$ at enrollment. However, among animals with low blood glucose at enrollment, extended PG treatment increased milk production by $3.4 \mathrm{~kg} / \mathrm{d}(95 \%$ CI: 1.7 to $5.1 ; P=0.0001)$ and $\mathrm{B}+\mathrm{C}$ treatment increased milk production by 3.1 $\mathrm{kg} / \mathrm{d}(95 \%$ CI: 1.3 to $5.0 ; P=0.01)$ compared with $3 \mathrm{~d}$ of $\mathrm{PG}$ treatment and no $\mathrm{B}+\mathrm{C}$.

\section{DISCUSSION}

The purpose of this study was to determine the effects of a butaphosphan-cyanocobalamin combination product and varying lengths of propylene glycol treatment on ketosis cure risk, blood BHB concentrations after treatment, and daily milk production in the first $30 \mathrm{~d}$ after enrollment. This is the first large-scale field

Table 5. Final model for blood BHB concentrations 2 wk after treatment, accounting for repeated measures, in 594 Holsteins from 9 herds $^{1}$

\begin{tabular}{|c|c|c|c|}
\hline Variable & $\beta$ coefficient & $\mathrm{SE}$ & $P$-value \\
\hline Intercept & -0.121 & 0.10 & 0.08 \\
\hline \multicolumn{4}{|l|}{ Enrollment BHB } \\
\hline 1.2 to $2.4 \mathrm{mmol} / \mathrm{L}$ & Referent & - & - \\
\hline$>2.4 \mathrm{mmol} / \mathrm{L}$ & 0.19 & 0.08 & 0.02 \\
\hline \multicolumn{4}{|l|}{ Glucose group } \\
\hline$<2.2 \mathrm{mmol} / \mathrm{L}$ & Referent & - & - \\
\hline$\geq 2.2 \mathrm{mmol} / \mathrm{L}$ & 0.24 & 0.07 & 0.001 \\
\hline \multicolumn{4}{|l|}{ Parity } \\
\hline 1 & Referent & - & - \\
\hline 2 & 0.38 & 0.10 & $<0.001$ \\
\hline $3+$ & 0.42 & 0.09 & $<0.001$ \\
\hline \multicolumn{4}{|l|}{$P G$} \\
\hline $3 \mathrm{~d}$ & -0.04 & 0.07 & 0.5 \\
\hline $5 \mathrm{~d}$ & Referent & - & - \\
\hline \multicolumn{4}{|l|}{$\mathrm{B}+\mathrm{C}$} \\
\hline Yes & -0.04 & 0.07 & 0.5 \\
\hline No & Referent & - & - \\
\hline
\end{tabular}

${ }^{1}$ Cows were randomly assigned to treatment with $10 \%$ butaphosphancyanocobalamin $(\mathrm{B}+\mathrm{C}$ ) and $5 \mathrm{~d}$ of $\mathrm{PG}$ (propylene glycol; $\mathrm{n}=124$ ), $\mathrm{B}+\mathrm{C}$ and $3 \mathrm{~d}$ of $\mathrm{PG}(\mathrm{n}=176)$, placebo and $5 \mathrm{~d}$ of $\mathrm{PG}(\mathrm{n}=128)$, or placebo and $3 \mathrm{~d}$ of $\mathrm{PG}(\mathrm{n}=166)$ at ketosis diagnosis between 3 and 16 DIM. Ketosis was defined as blood $\mathrm{BHB} \geq 1.2 \mathrm{mmol} / \mathrm{L}$. 
Table 6. Final model, accounting for repeated measures, for milk production $(\mathrm{kg} / \mathrm{d})$ in the first $30 \mathrm{~d}$ after treatment in 366 Holstein dairy cows from 3 herds $^{1}$

\begin{tabular}{|c|c|c|c|c|}
\hline Variable & $\begin{array}{l}\text { Milk difference } \\
\text { per day }(\mathrm{kg})\end{array}$ & $\mathrm{SE}$ & $P$-value & $95 \% \mathrm{CI}$ \\
\hline \multicolumn{5}{|l|}{ Parity } \\
\hline 1 & Referent & - & - & - \\
\hline 2 & 12.9 & 0.75 & $<0.001$ & 11.7 to 15.1 \\
\hline $3+$ & 15.3 & 0.79 & $<0.001$ & 13.5 to 17.0 \\
\hline \multicolumn{5}{|l|}{ Week of enrollment ${ }^{2}$} \\
\hline 1 & -2.4 & 0.57 & $<0.001$ & -1.3 to -3.5 \\
\hline 2 & Referent & - & - & - \\
\hline \multicolumn{5}{|l|}{ Month of calving } \\
\hline May & Referent & - & - & - \\
\hline June & -5.3 & 0.61 & $<0.001$ & -6.5 to -4.1 \\
\hline July & -7.1 & 0.61 & $<0.001$ & -8.3 to -5.9 \\
\hline \multicolumn{5}{|l|}{ Glucose group } \\
\hline$<2.2 \mathrm{mmol} / \mathrm{L}$ & Referent & - & - & - \\
\hline$\geq 2.2 \mathrm{mmol} / \mathrm{L}$ & -1.7 & 0.47 & $<0.001$ & -2.6 to -0.8 \\
\hline \multicolumn{5}{|l|}{$\overline{P G}$} \\
\hline $3 \mathrm{~d}$ & Referent & - & - & - \\
\hline $5 \mathrm{~d}$ & -0.28 & 0.45 & 0.5 & -1.2 to 0.6 \\
\hline \multicolumn{5}{|l|}{$\mathrm{B}+\mathrm{C}$} \\
\hline No & Referent & - & - & - \\
\hline Yes & 0.50 & 0.45 & 0.3 & -0.4 to 1.4 \\
\hline$P G \times$ glucose group & - & - & 0.005 & - \\
\hline $\mathrm{B}+\mathrm{C} \times$ glucose group & - & - & 0.04 & - \\
\hline
\end{tabular}

trial to use $\mathrm{B}+\mathrm{C}$ for ketosis treatment and to test the difference between 2 discrete durations of PG treatment in multiple herds. Extended PG treatment improved ketosis cure risk and decreased blood BHB concentrations after treatment in animals that had high blood BHB concentrations at enrollment and increased milk production in animals with low blood glucose at enroll- ment. Although $\mathrm{B}+\mathrm{C}$ did not affect ketosis cure risk or blood $\mathrm{BHB}$ concentrations, the effect of $\mathrm{B}+\mathrm{C}$ on milk production suggests it may be beneficial in animals with low blood glucose at enrollment. It is important to note that no animals were left completely untreated in this study because of the well-established effects of untreated ketosis (McArt et al., 2011, 2012a). Thus, we

Table 7. Stratum-specific model, accounting for repeated measures, for milk production $(\mathrm{kg} / \mathrm{d})$ in the first 30 $\mathrm{d}$ after treatment in Holstein dairy cows with blood glucose $<2.2 \mathrm{mmol} / \mathrm{L}(\mathrm{low}, \mathrm{n}=146$ ) and $\geq 2.2 \mathrm{mmol} / \mathrm{L}$ $(\mathrm{n}=220)$ at enrollment ${ }^{1}$

\begin{tabular}{|c|c|c|c|c|}
\hline Variable & $\begin{array}{l}\text { Milk difference } \\
\text { per day }(\mathrm{kg})\end{array}$ & $\mathrm{SE}$ & $P$-value & $95 \%$ CI \\
\hline \multicolumn{5}{|c|}{ Glucose at enrollment $<2.2 \mathrm{mmol} / \mathrm{L}$} \\
\hline $3 \mathrm{~d}$ & Referent & - & - & - \\
\hline $5 \mathrm{~d}$ & 3.4 & 0.87 & $<0.001$ & 1.7 to 5.1 \\
\hline \multicolumn{5}{|l|}{$\mathrm{B}+\mathrm{C}$} \\
\hline No & Referent & - & - & - \\
\hline Yes & 3.1 & 0.94 & 0.01 & 1.3 to 5.0 \\
\hline \multicolumn{5}{|c|}{$\begin{array}{l}\text { Glucose at enrollment } \geq 2.2 \mathrm{mmol} / \mathrm{L} \\
\mathrm{PG}\end{array}$} \\
\hline $3 \mathrm{~d}$ & Referent & - & - & - \\
\hline $5 \mathrm{~d}$ & -1.6 & 0.83 & 0.06 & -3.2 to 0 \\
\hline \multicolumn{5}{|l|}{$\mathrm{B}+\mathrm{C}$} \\
\hline No & Referent & - & - & - \\
\hline Yes & 0.21 & 0.80 & 0.8 & -1.4 to 1.8 \\
\hline
\end{tabular}

${ }^{1}$ Cows were randomly assigned to treatment with $10 \%$ butaphosphan-cyanocobalamin $(\mathrm{B}+\mathrm{C})$ and $5 \mathrm{~d}$ of $\mathrm{PG}$ (propylene glycol; $\mathrm{n}=89), \mathrm{B}+\mathrm{C}$ and $3 \mathrm{~d}$ of $\mathrm{PG}(\mathrm{n}=93)$, placebo and $5 \mathrm{~d}$ of $\mathrm{PG}(\mathrm{n}=91)$, or placebo and $3 \mathrm{~d}$ of PG $(\mathrm{n}=93)$ at ketosis diagnosis between 3 and 16 DIM. 
are assuming that $3 \mathrm{~d}$ of $\mathrm{PG}$ treatment afforded some benefit to all enrolled animals and we are examining the additional effects of $\mathrm{B}+\mathrm{C}$ or extended $\mathrm{PG}$ treatment.

Extended $\mathrm{PG}$ treatment improved ketosis cure risk and decreased blood BHB concentrations 1 wk after enrollment in animals with higher blood BHB concentrations at the time of enrollment $(>2.4 \mathrm{mmol} / \mathrm{L})$. Animals treated with PG for $5 \mathrm{~d}$ were 1.7 times more likely to cure than animals treated with $3 \mathrm{~d}$ of PG. However, in animals with blood BHB concentrations from 1.2 to $2.4 \mathrm{mmol} / \mathrm{L}$ at enrollment, we detected no difference between groups. Due to our study design, it is not possible to infer whether $3 \mathrm{~d}$ of $\mathrm{PG}$ is sufficient for cows with BHB from 1.2 to $2.4 \mathrm{mmol} / \mathrm{L}$ and the additional days of treatment provide no further benefit, or whether neither duration of PG therapy is beneficial in these cows. Propylene glycol helps in the treatment of ketosis by providing precursors for and stimulating gluconeogenesis (Nielsen and Ingvartsen, 2004). Increased glucose leads to decreased fat catabolism and decreased ketogenesis. The difference in effect seen based on enrollment BHB concentrations is likely due to animals with higher BHB concentrations being more severely affected. These animals may benefit from the effects of additional treatments with PG. However in animals with lower blood BHB concentrations, the stress of being handled and drenched 2 additional times might outweigh any benefits of the PG treatment.

The $\mathrm{B}+\mathrm{C}$ treatment had no effect on ketosis cure, maintenance of cure, or blood BHB concentrations at 1 and 2 wk after treatment. This is in contrast to previous studies that showed that $\mathrm{B}+\mathrm{C}$ decreased blood BHB concentrations (Lohr et al., 2006) and increased ketosis cure risk (Gordon et al., 2012). In the study by Lohr et al. (2006), the significant decrease in blood $\mathrm{BHB}$ concentrations after $\mathrm{B}+\mathrm{C}$ treatment was as a percent of the BHB concentration at enrollment, not as an absolute decrease in BHB concentrations. In fact, there was no difference between treatment groups at any time point when examined as actual BHB concentrations. In the preceding study (Gordon et al., 2012), $\mathrm{B}+\mathrm{C}$ significantly increased ketosis cure in animals with low blood glucose at enrollment, but had no effect in animals with blood glucose $\geq 2.2 \mathrm{mmol} / \mathrm{L}$ at enrollment. It is unclear why this interaction was not present in the current study, as blood glucose concentrations were similar in both studies.

As in the previous study conducted by our group (Gordon et al., 2012), B $+\mathrm{C}$ significantly increased milk production in the first $30 \mathrm{~d}$ after treatment in animals with low blood glucose concentrations at enrollment. Treatment with $\mathrm{B}+\mathrm{C}$ increased milk production by 3.1 $\mathrm{kg} / \mathrm{d}$ (95\% CI: 1.3 to 5.0 ) in animals with blood glucose $<2.2 \mathrm{mmol} / \mathrm{L}$ at the time of enrollment, but had no effect on production in animals with higher blood glucose. The mechanism for this increase in milk production is not completely clear. It has been hypothesized that animals with early lactation ketosis have some level of fat accumulation in the liver and a subsequent decrease in gluconeogenic capabilities of liver tissue (Holtenius and Holtenius, 1996; Herdt, 2000) and that $\mathrm{B}+\mathrm{C}$ stimulates gluconeogenesis (Rollin et al., 2010). Additionally, glucose is often limiting in cows in early lactation (Herdt, 2000), so an increase in blood glucose would likely increase milk production. Stimulation of gluconeogenesis in animals with normal blood glucose may not have a significant effect, because there is less homeorhetic drive to increase glucose levels. However, in animals where gluconeogenesis is impaired, stimulation may increase blood glucose levels and decrease ketogenesis and fat accumulation in the liver (Herdt, 2000), although we did not see an effect of treatment on blood BHB levels as might be expected.

A study examining the effects of administration of vitamin $\mathrm{B}_{12}$ around the time of calving (Preynat et al., 2009a,b) showed that administration of vitamin $\mathrm{B}_{12}$ increased blood glucose, which corresponded to an increase in milk production. However, animals in this study were treated with folic acid in conjunction with vitamin $\mathrm{B}_{12}$, so the effects of vitamin $\mathrm{B}_{12}$ alone are unknown. Furthermore, animals in the study by Preynat et al. $(2009 a, b)$ were treated weekly with 10 $\mathrm{mg}$ of cyanocobalamin, a much higher dose than that administered in the current study $(1.25 \mathrm{mg}$ per injection for a total of $3.75 \mathrm{mg}$ ). More research is required to understand the mechanism of $\mathrm{B}+\mathrm{C}$ and the relationship of this mechanism with blood glucose levels. However, the increased milk production seen in treated animals in 2 separate studies and in more than one herd suggests that $\mathrm{B}+\mathrm{C}$ may be beneficial for ketotic animals with low blood glucose at enrollment $(<2.2 \mathrm{mmol} / \mathrm{L})$.

We also detected a significant interaction between blood glucose concentrations at enrollment and treatment with PG. Animals with blood glucose $<2.2$ $\mathrm{mmol} / \mathrm{L}$ at the time of ketosis diagnosis produced 3.4 $\mathrm{kg} / \mathrm{d}$ (95\% CI: 1.7 to 5.1) more milk in the $30 \mathrm{~d}$ after treatment if treated with $5 \mathrm{~d}$ of $\mathrm{PG}$ versus $3 \mathrm{~d}$. In contrast, animals that had blood glucose at enrollment $\geq 2.2 \mathrm{mmol} / \mathrm{L}$ tended $(P=0.06)$ to produce less milk $(-1.6 \mathrm{~kg} / \mathrm{d}, 95 \% \mathrm{CI}:-3.2$ to 0$)$ per day if treated with $5 \mathrm{~d}$ of PG. Because PG acts as a glucose precursor, this would likely increase the amount of glucose available and subsequently increase milk production (Nielsen and Ingvartsen, 2004). Again, in animals with low blood glucose, the effect would likely be larger, as there is a homeostatic and homeorhetic drive to increase blood glucose concentrations. Increased blood glucose should decrease lipolysis and ketogenesis to decrease 
the effects of hyperketonemia on production as well. A recent study found that treatment with PG increased milk production in animals treated for ketosis, but this increase was dependent on herd of origin (McArt et al., 2011). We did not see similar effects of herd in this study. The increase in milk we observed in response to PG treatment in the current study was higher than that observed by McArt et al. (2011). However, they did not measure blood glucose and thus could not look at the conditional association between glucose concentrations and milk production.

Additionally, animals in the study by McArt et al. (2011) were tested 3 times a week and treated until blood BHB concentrations were $<1.2 \mathrm{mmol} / \mathrm{L}$ or $\geq 3.0$ $\mathrm{mmol} / \mathrm{L}$, or the animals reached 16 DIM (2 to $13 \mathrm{~d}$ duration of treatment). Thus, even though the time of eligibility for enrollment in both studies was similar, there are too many differences in study design to make a direct comparison of the magnitude of treatment effects.

The lack of benefit of 2 additional days of treatment with PG in animals with blood glucose $\geq 2.2 \mathrm{mmol} / \mathrm{L}$ at the time of diagnosis may be because gluconeogenesis is not stimulated by the administration of PG in these animals or not stimulated to the same amount as animals with low blood glucose. The lack of benefit combined with the fact that restraining animals for administration of an oral drench may be stressful and stress can reduce feed intake (Ingvartsen, 2006) might explain the trend for decreased production in animals with blood glucose $\geq 2.2 \mathrm{mmol} / \mathrm{L}$ at ketosis diagnosis.

The relationship of blood glucose concentrations at enrollment with treatment effects on ketosis cure risk, blood BHB concentrations 1 and 2 wk after enrollment, and milk production in the first $30 \mathrm{~d}$ after enrollment is a novel finding. The relationship between blood glucose concentrations and ketosis has been used to classify ketosis (Sakai et al., 1993; Holtenius and Holtenius, 1996). However, the relationship has not been studied in a large-scale clinical trial on ketosis treatment. This is the second study from our group to show that low blood glucose at the time of ketosis diagnosis decreases risk of cure, increases blood BHB concentrations in the 2 wk after enrollment, and affects milk production in the $30 \mathrm{~d}$ after enrollment. Holtenius and Holtenius (1996) suggested that cows with low blood glucose were animals in which gluconeogenesis was maximally stimulated and further production of glucose was limited by lack of gluconeogenic precursors. These animals were generally diagnosed during peak production. They also suggested that animals diagnosed around the time of parturition tended to have normal to high blood glucose and some level of fat accumulation in the liver. We did not measure liver fat content of enrolled animals, so the status of enrolled animals in regard to fatty liver is unknown. However, this suggests that there is more to learn about the relationship between blood glucose and blood BHB concentrations and the potential differences in mechanisms of ketosis development in early lactation animals.

Although $\mathrm{B}+\mathrm{C}$ did not affect ketosis resolution or blood BHB concentrations, it can still be recommended as an adjunct to $\mathrm{PG}$ treatment to increase production in animals with low blood glucose $(<2.2 \mathrm{mmol} / \mathrm{L})$ at the time of ketosis diagnosis. Furthermore, $5 \mathrm{~d}$ of $\mathrm{PG}$ therapy can be recommended in animals with blood BHB concentrations $>2.4 \mathrm{mmol} / \mathrm{L}$ or blood glucose concentrations $<2.2 \mathrm{mmol} / \mathrm{L}$ at the time of ketosis diagnosis.

\section{CONCLUSIONS}

These results show the benefit to ketosis resolution of extended PG therapy for animals with higher blood $\mathrm{BHB}$ concentrations at enrollment. Both PG and B+C treatment can increase early lactation milk production in animals with low blood glucose at the time of ketosis diagnosis. Blood glucose may be an important predictor of treatment efficacy for ketosis and more research is required to understand the relationship between blood BHB and glucose concentrations in ketotic animals.

\section{ACKNOWLEDGMENTS}

Funding and in-kind support for this project was provided by Ontario Ministry of Agriculture and Food (Guelph, ON, Canada), Bayer Animal Health (Shawnee, KS), Vetoquinol (Lavaltrie, QC, Canada), and the American Association of Bovine Practitioners Research Assistantship (Auburn, AL). The authors thank David Renaud and Brittany Scace of the Ontario Veterinary College (Guelph, ON, Canada) and Jennifer Smith, Vanessa Kane, and Jeffery Arthur of Michigan State University (East Lansing) for their assistance with data collection as well as the participating herd owners and managers.

\section{REFERENCES}

Baird, G. D. 1982. Primary ketosis in the high-producing dairy cow: Clinical and subclinical disorders, treatment, prevention, and outlook. J. Dairy Sci. 65:1-10.

Bauman, D. E., and W. B. Currie. 1980. Partitioning of nutrients during pregnancy and lactation: A review of mechanisms involving homeostasis and homeorhesis. J. Dairy Sci. 63:1514-1529.

Duffield, T. F., K. D. Lissemore, B. W. McBride, and K. E. Leslie. 2009. Impact of hyperketonemia in early lactation dairy cows on health and production. J. Dairy Sci. 92:571-580.

Gordon, J. L. 2013. Risk factors for and treatment of ketosis in lactating dairy cattle. DVSc Thesis. University of Guelph, Guelph, Ontario, Canada. 
Gordon, J. L., S. J. LeBlanc, L. Neuder, T. H. Herdt, D. F. Kelton, and T. F. Duffield. 2012. Efficacy of a combination butaphosphan and cyanocobalamin product and insulin for ketosis treatment. J. Dairy Sci. 95(Suppl. 2):177. (Abstr.)

Herdt, T. H. 2000. Ruminant adaptation to negative energy balance. Vet. Clin. North Am. Food Anim. Pract. 16:215-230.

Holtenius, P., and K. Holtenius. 1996. New aspects of ketone bodies in energy metabolism of dairy cows: A review. Zentralbl. Veterinarmed. A 43:579.

Ingvartsen, K. L. 2006. Feeding and management related diseases in the transition cow: Physiological adaptations around calving and strategies to reduce feeding related diseases. Anim. Feed Sci. Technol. 126:175-213.

Iwersen, M., U. Falkenberg, R. Voigtsberger, D. Forderung, and W. Heuwieser. 2009. Evaluation of an electronic cowside test to detect subclinical ketosis in dairy cows. J. Dairy Sci. 92:2618-2624.

Johnson, R. B. 1954. The treatment of ketosis with glycerol and propylene glycol. Cornell Vet. 44:6-21.

Kennedy, D. G., A. Cannavan, A. Molloy, F. O'Harte, S. M. Taylor, S. Kennedy, and W. J. Blanchflower. 1990. Methylmalonyl-CoA mutase (EC 5.4.99.2) and methionine synthetase (EC 2.1.1.13) in the tissues of cobalt-vitamin 12 deficient sheep. Br. J. Nutr. 64:721-732.

Lohr, B., B. Brunner, H. Janowitz, M. Hummel, T. Seeger, I. Weber, T. Wittek, B. Schmidt, and K. Hellmann. 2006. Clinical efficacy of Catosal ${ }^{\circledR}$ in the treatment of ketosis in cows with left abomasal displacement. Tierarztl. Umsch. 61:187-190.

Maplesden, D. C. 1954. Propylene glycol in the treatment of ketosis. Can. J. Comp. Med. Vet. Sci. 18:287-293.

McArt, J. A., D. V. Nydam, and G. R. Oetzel. 2012a. A field trial on the effect of propylene glycol on displaced abomasum, removal from herd, and reproduction in fresh cows diagnosed with subclinical ketosis. J. Dairy Sci. 95:2505-2512.

McArt, J. A., D. V. Nydam, and G. R. Oetzel. 2012b. Epidemiology of subclinical ketosis in early lactation dairy cattle. J. Dairy Sci. 95:5056-5066.

McArt, J. A., D. V. Nydam, P. A. Ospina, and G. R. Oetzel. 2011. A field trial on the effect of propylene glycol on milk yield and resolution of ketosis in fresh cows diagnosed with subclinical ketosis. J. Dairy Sci. 94:6011-6020.
Nielsen, N. I., and K. L. Ingvartsen. 2004. Propylene glycol for dairy cows. Anim. Feed Sci. Technol. 115:191-213.

Ospina, P. A., D. V. Nydam, T. Stokol, and T. R. Overton. 2010a. Associations of elevated nonesterified fatty acids and beta-hydroxybutyrate concentrations with early lactation reproductive performance and milk production in transition dairy cattle in the northeastern United States. J. Dairy Sci. 93:1596-1603.

Ospina, P. A., D. V. Nydam, T. Stokol, and T. R. Overton. 2010b. Association between the proportion of sampled transition cows with increased nonesterified fatty acids and beta-hydroxybutyrate and disease incidence, pregnancy rate, and milk production at the herd level. J. Dairy Sci. 93:3595-3601.

Preynat, A., H. Lapierre, M. C. Thivierge, M. F. Palin, J. J. Matte, A. Desrochers, and C. L. Girard. 2009a. Effects of supplements of folic acid, vitamin B12, and rumen-protected methionine on whole body metabolism of methionine and glucose in lactating dairy cows. J. Dairy Sci. 92:677-689.

Preynat, A., H. Lapierre, M. C. Thivierge, M. F. Palin, J. J. Matte, A. Desrochers, and C. L. Girard. 2009b. Influence of methionine supply on the response of lactational performance of dairy cows to supplementary folic acid and vitamin B12. J. Dairy Sci. 92:16851695.

Rollin, E., R. D. Berghaus, P. Rapnicki, S. M. Godden, and M. W. Overton. 2010. The effect of injectable butaphosphan and cyanocobalamin on postpartum serum beta-hydroxybutyrate, calcium, and phosphorus concentrations in dairy cattle. J. Dairy Sci. 93:978-987.

Sakai, T., T. Hayakawa, M. Hamakawa, K. Ogura, and S. Kubo. 1993. Therapeutic effects of simultaneous use of dextrose and insulin in ketotic dairy cows. J. Dairy Sci. 76:109-114.

Studer, V. A., R. R. Grummer, and S. J. Bertics. 1993. Effect of prepartum propylene glycol administration on perlparturient fatty liver in dairy cows. J. Dairy Sci. 76:2931-2939.

Wittrock, J. A. M., T. F. Duffield, S. Riuzzi, and S. J. LeBlanc. 2013. Evaluation of an electronic cow-side glucose meter for diagnosing insulin resistance in Holstein dairy cows. J. Dairy Sci. 96:45144518 . 